ARTIKEL

Filsafat Politik Nurcholish Madjid

Muhammad Saleh Tajuddin

Kedaulatan Rakyat dalam Pemikiran Filsafat

Politik Montesquieu

Fajrul Ilmy Darussalam \& Andi Batara Indra

$189-204$

Politik Multikulturalisme: Sebuah Gerakan Keadilan

dan Kesetaraan

Muhaemin Latif

$205-229$

Kompetisi, Kompromi dan Coalition Agreement: Berebut

Kursi Wakil Gubernur DKI Jakarta di Tengah

Kontestasi Pemilihan Presiden 2019

Mahpudin \& Fransisca Mega Lestari

$230-259$

Kegagalan Keterlibatan Politik: Dari Kesenjangan Digital

Menuju Kesenjangan Demokrasi

Fairuz Arta Abhipraya \& Bambang Eka Cahya Widodo

Mobilisasi Massa Kemenangan Kolom Kosong Pada Pemilihan Walikota Makassar Tahun 2018

Gustiana Kambo

Kinerja Komisi Pemilihan Umum Kota Makassar dalam

Melindungi Hak Pilih Warga di Tengah

Pandemi COVID-19

Dyahwanti Sulistyowati, Muhammad, Sukri \& Ariana

Isu Pemekaran Wilayah Sebagai Komoditas Politik Dalam Masyarakat

To Pulo di Kepulauan Selayar

Dwi Indriani \& Sudarmono

Penanganan Konflik Melalui Keamanan di Kalimantan Barat 


\title{
KOMPETISI, KOMPROMI DAN COALITION AGREEMENT: BEREBUT KURSI WAKIL GUBERNUR DKI JAKARTA DI TENGAH KONTESTASI PEMILIHAN PRESIDEN 2019
}

\author{
Mahpudin $^{1}$ \& Fransisca Mega Lestari ${ }^{2}$ \\ Departemen Politik Pemerintahan, Universitas Gadjah Mada ${ }^{1,2}$ \\ Email: mahpudin95@mail.ugm.ac.id ${ }^{1}$, fransisca.megalestari@mail.ugm.ac.id ${ }^{2}$
}

\begin{abstract}
Abstrak
Kompetisi dan kompromi dalam koalisi partai merupakan sebuah keniscayaan dalam sistem politik multipartai dan pemilu proporsional. Hal ini terjadi karena partai memiliki agenda, kepentingan, dan tujuan politik yang berbeda. Pilihan partai untuk berkompetisi atau berkompromi sangat bergantung pada situasi dan kepentingan politik seperti apa yang sedang dihadapi. Implikasinya, pilihan tersebut bisa bersifat tunggal, yaitu memilih salah satu (kompetisi atau kompromi dengan partai lain), atau keduanya berjalan beriringan. Oleh karena itu, partai sering kali membuat kontrak politik berupa coalition agreement untuk memastikan koalisi yang dibangun memberikan keuntungan politik. Artikel ini berupaya memotret kompetisi dan kompromi di internal partai koalisi antara Gerindra dan PKS. Hasil kajian menunjukkan bahwa Gerindra dan PKS harus mendamaikan dua logika. Di satu sisi, kedua partai ini harus menunjukkan persatuan saat pemilihan presiden 2019 untuk suksesi pencalonan Prabowo-Sandiaga Uno. Namun, di saat yang bersamaan mereka saling bersaing dalam konteks pengisian jabatan wakil gubernur Jakarta. Pilihan untuk berkompetisi dan berkompromi berimplikasi pada hadirnya coalition agreement diantara partai koalisi. Namun, coalition agreement tidak berorientasi pada isu-isu kebijakan, melainkan lebih berpijak pada kepentingan kekuasaan. Implikasinya, coalition agreement menjadi perekat sekaligus penghancur bangunan koalisi partai.
\end{abstract}

\section{Kata Kunci:}

Kompetisi, Kompromi, Koalisi, Coalition Agreement

\begin{abstract}
Competition and compromise in party coalitions is a necessity. This happens because parties have different agendas, interests, and political goals. The party's choice to compete or compromise is highly dependent on the political situation and interests that are being faced. The implication is that the choice can be single, namely choosing one (competition or compromise with other parties), or both go hand in hand. Therefore, parties often make political contracts in the form of coalition agreements to ensure that the coalitions that are built provide political benefits. This article attempts to portray competition and compromise within the coalition party between Gerindra and PKS. The results of the study show that Gerindra and PKS must reconcile the two logics. On the one hand, these two parties must show unity during the 2019 presidential election for the succession of the Prabowo-Sandiaga Uno candidacy. However, at the same time they are competing in the context of filling the position of deputy governor. The two
\end{abstract}


competing logics caused the coalition parties to compete and at the same time compromise. The choice to compete and compromise has implications for the presence of a coalition agreement among coalition parties. However, the coalition agreement is not oriented to policy issues, but rather is based on the interests of power. The implication is that the coalition agreement becomes the glue as well as the destroyer of the party coalition building.

\section{Keywords: \\ Competition, Compromise, Coalition, Coalition Agreement}

\section{Pendahuluan}

Artikel ini membahas tentang kompetisi dan kompromi antar partai politik yang tergabung dalam koalisi yang sama sebagai pengusung pasangan calon kepala daerah dalam memperebutkan kekosongan kursi jabatan wakil gubernur. Koalisi yang dimaksud adalah partai Gerindra dan PKS yang mengusung Anis Baswedan-Sandiaga Uno sebagai gubernur dan wakil gubernur DKI Jakarta periode 2017-2022. Pencalonan Sandiaga Uno sebagai calon kandidat di Pemilu Presiden (Pilpres) tahun 2019 menyebabkan kekosongan kursi wakil gubernur DKI Jakarta. Kondisi ini memicu partai politik pengusung melakukan negosiasi politik untuk memilih calon pemimpin yang akan menggantikan posisi Sandiaga Uno. Hal ini menjadi pemicu terjadinya tarik menarik kepentingan politik antara Gerindra dan PKS yang menyebabkan selama lebih dari 2 tahun, Jakarta belum memiliki wakil gubernur. ${ }^{1}$

Undang-undang Nomor 10 tahun 2016 menyebut bahwa apabila terjadi kekosongan jabatan wakil gubernur dengan sisa masa jabatan lebih dari 18 bulan, maka partai politik pengusung berwenang merekomendasikan sebanyak dua nama calon alternatif dan selanjutnya diserahkan ke DPRD untuk dipilih satu nama yang akan diangkat secara resmi menjadi wakil gubernur definitif. Aturan ini secara eksplisit menunjukkan bahwa partai koalisi memiliki kekuasaan dalam menentukan proses pengisian kekosongan jabatan wakil gubernur. Pada saat yang bersamaan, aturan ini sekaligus memaksa partai politik untuk melakukan berbagai strategi dan manuver politik di arena legislatif. Implikasinya, isu pengisian kekosongan jabatan wakil kepala

${ }^{1}$ Luthfia Ayu Azanella, "2 Tahun Anies Pimpin Jakarta Tanpa Wakil. Pencapaian Hingga Kontroversi” dalam https://www.google.com/amp/s/amp.kompas.com/-tren/read/2019/10/16/160000965/ 2-tahun-anies-pimpin-jakarta-tanpa-wakil-pencapaian-hingga-kontroversi diakses 9 Januari 2021. 
daerah menjadi kompleks karena tidak hanya melibatkan negosiasi politik antara partai pengusung, tetapi juga dengan partai politik non pengusung di DPRD.

Menariknya, isu kekosongan wakil gubernur di tengah perhelatan Pilpres 2019 turut mempengaruhi relasi politik yang terjalin antara Gerindra dan PKS serta partai politik lainnya di DPRD DKI Jakarta. Hal ini tidak lepas sebab pola koalisi partai politik di DKI Jakarta sama dengan peta koalisi yang terbangun di tingkat nasional khususnya pada saat kontestasi Pilpres 2019 berlangsung. Gerindra dan PKS kembali berkoalisi mengusung Prabowo Subianto dan Sandiaga Uno sebagai calon presiden dan wakil presiden periode 2019-2024. Diskursus tentang kekosongan wakil gubernur bersamaan dengan berlangsungnya Pilpres 2019 telah menghadirkan logika kompetisi dan kompromi di antara partai politik. Bagaimana kompetisi dan kompromi dalam koalisi partai bekerja menjadi pertanyaan kunci yang hendak dijawab dalam artikel ini.

Menurut Mietzner, ${ }^{2}$ kompetisi dan kompromi antar partai politik mengalami pergeseran yang sangat radikal dalam sejarah kepartaian di Indonesia. Kompetisi partai di era 1950-an cenderung bersifat sentrifugal karena terdapat garis demarkasi ideologi partai dan dukungan massa yang cukup tajam di antara partai-partai sehingga situasi politik saat itu berpotensi terhadap konflik politik. Namun sejak era reformasi, persaingan antar partai justru mengarah pada sentripetal yang ditandai lenturnya ideologi partai, basis massa partai melemah, dan pragmatisme partai yang cenderung hanya berorientasi pada kekuasaan. Argumen Mietzner diperkuat oleh tesis $\operatorname{Slater}^{3}$ dan Ambardi ${ }^{4}$ bahwa partai-partai paska reformasi menunjukkan tidak ada persaingan substantif yang berpijak pada agenda kebijakan dan platform ideologi. Partai justru saling berkompromi untuk memperoleh akses terhadap kekuasaan. Karakter ini dikenal dengan sebutan partai kartel yang mana pilihan untuk bersaing atau berkompromi yang dijalankan oleh partai politik lebih menjelaskan kepentingan politik apa yang sedang diperebutkan.

\footnotetext{
${ }^{2}$ Marcus Mietzner, “Comparing Indonesia's Party Systems of The 1950s and The Post-Suharto era: From centrifugal to centripetal inter-party competition" dalam Journal of Southeast Asian Studies, Vol.39 No 3 (2008), h. 431-453.

${ }^{3}$ Dan Slater, "Indonesia's Accountability Trap: Party Cartel and Presidential Power After Democratic Transition" dalam Journal of Indonesia, Vol.78 (2004), h. 61-92.

${ }^{4}$ Kuskridho Ambardi, Mengungkap Politik Kartel: Studi Tentang Sistem Kepartaian di Indonesia Era Reformasi (Jakarta: Kepustakaan Populer Gramedia, 2009).
} 
Persaingan dan kompromi dapat terjadi dalam koalisi partai. Koalisi partai menjadi sebuah keniscayaan dalam sebuah negara yang menganut sistem multipartai di mana sulit memunculkan partai yang tampil dominan. Implikasinya, untuk suksesi pencalonan, partai terpaksa membangun kerjasama dengan partai lain untuk dapat mengusung pasangan calon. Pilihan koalisi bahkan telah diatur dalam regulasi kepemiluan. Konteks Pilkada misalnya, Undang-Undang Nomor 10 tahun 2016 menyebut bahwa partai atau gabungan partai dapat mengusung pasangan calon dengan syarat minimal memperoleh 25\% kursi di DPRD. Dengan kata lain partai dipaksa untuk membuka ruang negosiasi politik dengan partai lain untuk proses kandidasi. Ruang negosiasi inilah yang memunculkan strategi bersaing dan berkompromi dalam koalisi ${ }^{5}$. Paling tidak, terdapat dua pendekatan yang menjelaskan orientasi sebuah koalisi partai yaitu policy seeking dan office seeking. ${ }^{6}$ Pendekatan policy seeking menempatkan koalisi ditentukan atas dasar kebijakan apa yang hendak dicapai oleh partai politik, sehingga koalisi menekankan pada unsur kesamaan haluan ideologi dan orientasi kebijakan. Sedangkan pendekatan office seeking mendudukkan koalisi partai sebagai entitas tunggal yang sama-sama bertujuan memaksimalkan kekuasaan dengan mengabaikan prinsip perbedaan ideologi dan arah kebijakan partai. ${ }^{7}$

Di lain pihak, partai koalisi sering kali menimbulkan gesekan antar partai karena di dalamnya terdapat berbagai kepentingan politik. Oleh karena itu, pada umumnya partai koalisi akan membentuk "coalition agreement” untuk menjaga agar koalisi tetap bertahan. ${ }^{8}$ Coalition agreement tidak dapat dinafikan oleh sebuah pemerintahan yang terbentuk melalui koalisi partai. Oleh karena itu, keberhasilan tata kelola pemerintahan membutuhkan kompromi politik di antara partai politik. ${ }^{9}$ Artikel ini mengungkap bagaimana Partai Gerinda dan PKS sebagai partai pengusung pemerintah DKI Jakarta

\footnotetext{
${ }^{5}$ Arend Lijphart, Patterns of Democracy: Goverment Forms and Performance in Thirty-Six Countries (New Heaven: Yale University Press, 1999).

${ }^{6}$ Michael Laver \& Kenneth Shepsle, "Coalition and Cabinet Government" dalam The American Political Science Review, Vol. 84, No. 3 (1990), h. 873-890.

${ }^{7}$ William Harrison Riker, The Theory of Political Coalitions (New Haven: Yale University Press, 1962).

${ }^{8}$ Lanny W. Martin \& Georg Vanberg, Parliaments and Coalitions: The Role of Legislative Institutions in Multiparty Governance (Oxford: Oxford University Press, 2011); Baca juga Wolfgang C. Muller \& Thomas M. Meyer, "Meeting the Challenges of Representation and Accountability in Multiparty Governments" dalam West European Politics, Vol.33, No. 5 (2010), h.1065-1092.

${ }^{9}$ Paul Warwick, Government Survival in Parliamentary Democracies (Cambridge: Cambridge University Press, 1994).
} 
melakukan coalition agreement dalam merespon isu tentang kekosongan kursi wakil gubernur. Coalition agreement ini membentuk relasi partai kolasi dalam berkompetisi sekaligus berkompromi.

Kajian tentang kompetisi dan kompromi dalam koalisi partai telah banyak dihasilkan. Studi Sagarzazu \& Kluver ${ }^{10}$ membahas bagaimana koalisi partai politik pemerintah saling berkompetisi meraih dukungan suara pemilih menjelang pemilu legislatif namun di saat yang bersamaan harus menunjukkan persatuan dan kompromi di pemerintahan terutama dalam menjalankan agenda kebijakan bersama. Studi lain menekankan fokus kajian tentang kompetisi dan kompromi dalam koalisi partai untuk mencari keuntungan kebijakan (policy seeking) atau akses terhadap kekuasaan dan jabatan (office seeking) di pemerintahan. ${ }^{11}$ Sementara, studi Moury \& Timmermans, ${ }^{12}$ Vercesi, ${ }^{13}$ dan Bradshaw \& Breakfast ${ }^{14}$ mengungkap bahwa koalisi partai berpotensi terhadap konflik politik baik yang terjadi di intra maupun inter-koalisi partai. Mereka menekankan pentingnya manajemen konflik dan kesepakatan koalisi (coalition agreement) untuk mengatasi konflik partai.

Berkaitan dengan coalition agreement, berbagai literatur menunjukkan kontrak politik pada koalisi partai lebih banyak membahas pada tingkat nasional. Coalition agreement yang dibangun oleh partai berorientasi pada isu-isu kebijakan karena terkoneksi langsung terhadap efektifitas kinerja pemerintahan koalisi, kesesuaian ideologi partai, dan dukungan pemilih. ${ }^{15}$ Coalition agreement umumnya ditemukan

${ }^{10}$ Inaki Sagarzazu \& Heike Kluver, "Coalition Goverment and Party Competition: Political Communication Strategies of Coalition Parties” dalam Political Science Reserach and Metods, Vol. 5, No 2 (2017), h. 333-349.

${ }^{11}$ Kuskridho Ambardi, Loc.Cit.; Hanna Back, Marc Debus \& Patrick Dumont, "Who Gets What in Coalition Governments? Predictors of Portfolio Allocation in Parliamentary Democracies" dalam European Journal of Political Research, Vol.50 (2011), h. 441-478; Marc Debus \& Martin Gross, "Coalition Formation at The Local Level: Institutional Constraints, Party Policy Conflict, and Office Seeking Political Parties" dalam Party Politics, Vol.22, No.6 (2015), h. 835-846.

${ }^{12}$ Catherine Moury \& Arco Timmermans, "Inter-Party Conlict Management in Coalition Goverment: Analyzing The Role of Coalition Agreement in Belgium, Germany, Italy, and The Netherlands" dalam Politics and Governance, Vol.1, No. 2 (2013), h.117-131.

${ }^{13}$ Michelangelo Vercesi, "Coalition Politics and Inter-Party Conlict Management: A Theoritical Framework" dalam Politics and Policy, Vol.44, No. 2 (2016), h.168-219.

${ }^{14}$ Gavin Bradshaw \& Ntsikelelo Breakfast, "Mediating Coalition Politics at The Local Goverment Level in South Africa, 2016-2019" dalam Journal of Gender, Information, and Development in Africa (JGIDA), Special Issue (2019), h.113-129.

${ }^{15}$ Heike Kluver \& Hanna Back, "Coalition Agreements, Issue Attention, and Cabinet Governance” dalam Comparative Political Study, Vol. 52, No. 13-14 (2019), h. 1995-2031; Catherine Moury, "Coalition agreement and party mandate: How Coalition Agreements Constrain the Ministers" dalam Party Politics, Vol. 17, No.3 (2011), h. 385-404. 
pada negara yang menganut sistem multipartai dengan pemilu proporsional baik pada pemerintahan presidensial maupun parlementer. ${ }^{16}$ Oleh karena itu, artikel ini selain memperkaya kajian tentang kompetisi, kompromi, dan coalition agreement dalam koalisi partai, juga memberi efek pembeda. Coalition agreement dalam kasus yang kami angkat berfokus pada arena lokal yaitu konteks kompetisi dan kompromi di antara partai politik koalisi pemerintah lokal di DKI Jakarta, yaitu Partai Gerindra dan PKS dalam memperebutkan jabatan wakil gubernur. Selain itu, artikel ini juga mengelaborasi konteks pemilu nasional yaitu Pilpres 2019 sebagai bagian yang tidak dapat dipisahkan dalam membentuk logika kompetisi dan kompromi yang dijalankan oleh kedua partai tersebut baik di internal koalisi partai pengusung antara Gerindra dan PKS maupun non koalisi partai pengusung di DPRD DKI Jakarta.

Artikel ini menunjukkan bahwa terdapat kemiripan peta koalisi di tingkat lokal dan nasional, sehingga isu politik di lokal maupun nasional turut mempengaruhi dinamika politik di internal koalisi termasuk relasi dengan partai lain non koalisi. Sebagai partai koalisi, partai Gerinda dan PKS menjalankan dua logika yang saling bersaing. Di satu sisi mereka harus menunjukkan kompromi untuk kepentingan suksesi Pilpres 2019. Namun, di sisi yang lain pada saat yang bersamaan, dua partai ini saling berkompetisi memperebutkan kursi wakil gubernur Jakarta. Sementara, coalition agreement yang dibangun tidak berorientasi pada isu-isu kebijakan, melainkan lebih berpijak pada kepentingan kekuasaan. Implikasinya, agreement coalition menjadi perekat sekaligus penghancur bangunan koalisi partai.

\section{Metode Penelitian}

Artikel ini menggunakan jenis penelitian kualitatif dengan pendekatan analisis deskriptif. Pendekatan ini dipilih karena relevan dalam menjawab kebutuhan penelitian guna memperoleh pemahaman secara mendalam terkait sebuah kasus atau fenomena sosial. Sebagaimana diungkap oleh Nazir ${ }^{17}$ bahwa analisa deskriptif bertujuan untuk mendapatkan pemahaman yang komprehensif terhadap suatu kasus atau fenomena melalui data dan fakta-fakta dengan interpretasi yang tepat. Adapun kasus yang

\footnotetext{
${ }^{16}$ Adrian Albala, "When Do Coalitions Form Under Presidentialism, and Why Does It Matter? A Configurational Analysis From Latin America" dalam Politics, Vol. 41, No.3 (2021), h. 351-370.

${ }^{17}$ Moh. Nazir, Metode Penelitian (Jakarta : Salemba Empat, 2003).
} 
dimaksud pada artikel ini berkaitan dengan kompetisi dan kompromi di partai koalisi dalam memperebutkan jabatan wakil gubernur DKI Jakarta.

Pengumpulan data dilakukan melalui studi literatur terhadap sejumlah bahan bacaan yang relevan berkaitan dengan fokus dan lokus pada penelitian ini. Bahan bacaan yang dimaksud dapat berupa buku, artikel dan jurnal. Sementara data atau informasi terkait diperoleh dari media online. Untuk teknik analisa data menggunakan pendapat $\mathrm{Creswe}^{18}$ yaitu organisasi data, membuat deskripsi data, klarifikasi data dan langkah terakhir menginterpretasikan data.

\section{Pilkada DKI Jakarta 2017: Koalisi dan Peta Kekuatan Partai Politik}

DKI Jakarta sebagai arena politik, memiliki daya magnet yang luar biasa besar bagi banyak orang dibandingkan dengan daerah lain. Hal ini disebabkan karena DKI Jakarta sebagai ibukota negara sehingga menjadi barometer politik nasional. Keberhasilan Jokowi yang terpilih sebagai presiden RI pada Pilpres 2014 berangkat dari kepemimpinan sebagai Gubernur DKI Jakarta Periode 2012-2017. Oleh karena itu, Jakarta kerap dikaitkan sebagai arena kaderisasi bagi siapa saja yang hendak mencalonkan diri sebagai calon presiden. Implikasinya, posisi Gubernur dan Wakil Gubernur sangat menarik tidak hanya bagi partai politik tetapi juga bagi calon kandidat yang ingin membangun popularitas dan elektabilitas termasuk sebagai tangga jalan bagi karir politik aktor politik dan partai di tingkat nasional.

Status keistimewaan yang dimiliki DKI Jakarta menyebabkan desain kontestasi elektoral berbeda dengan daerah yang lain terutama mengenai syarat kemenangan pasangan calon. Hanya DKI Jakarta yang memiliki aturan adanya Pilkada dengan dua putaran. Hal ini sesuai dengan amanat Undang-Undang Nomor 29 tahun 2007 tentang Kekhususan DKI Jakarta bahwa dalam hal Pilkada, pasangan calon gubernur dan wakil gubernur dapat dinyatakan memenangkan pertarungan apabila memperoleh suara lebih dari 50\% dari jumlah suara sah saat Pilkada diselenggarakan. Apabila perolehan suara pasangan calon tidak mencapai 50\%, maka dilakukan Pilkada putaran kedua.

\footnotetext{
${ }^{18}$ John W. Creswell, Penelitian Kualitatif \& Desain Riset, edisi 3 (Yogyakarta: Pustaka Pelajar, 2004).
} 
Hasil Pileg periode 2014-2019 menjadi krusial karena dasar pijakan bagai partai dalam mengusung pasangan calon pada Pilkada DKI Jakarta 2017. Berikut ini perolehan kursi partai di DPRD Jakarta periode tersebut.

Tabel 1.

Jumlah Perolehan Kursi Partai di DPRD DKI Jakarta Periode 2014-2019

\begin{tabular}{|l|c|}
\hline \multicolumn{1}{|c|}{ Partai } & Kursi \\
\hline PDIP & 28 \\
\hline Gerindra & 15 \\
\hline PKS & 11 \\
\hline Demokrat & 10 \\
\hline PPP & 10 \\
\hline Hanura & 10 \\
\hline Golkar & 9 \\
\hline PKB & 6 \\
\hline Nasdem & 5 \\
\hline PAN & 2 \\
\hline Jumlah Kursi & 106 \\
\hline
\end{tabular}

Sumber data: Diolah oleh peneliti

Pilkada 2017 mengkontestasikan antara 3 pasangan calon yang diusung oleh koalisi partai politik yaitu 1) Pasangan Agus Harimurti Yudhoyono dan Sylviana Murni, sebagaimana nampak pada tabel berikut; 2) Pasangan Basuki Tjahaja Purnama (Ahok) dan Djarot Saiful Hidayat; 3) Pasangan Anies Baswedan dan Sandiaga Uno. Berikut gambaran lengkap koalisi partai pengusung dan jumlah kursi di DPRD.

Tabel 2.

Koalisi Partai Pengusung Pasangan Calon Gubernur dan Wakil Gubernur DKI Jakarta Pada Pilkada 2017

\begin{tabular}{|l|l|c|}
\hline \multicolumn{1}{|c|}{ Pasangan Calon } & \multicolumn{1}{|c|}{ Koalisi Partai Pengusung } & Jumlah Kursi di DPRD \\
\hline $\begin{array}{l}\text { Agus Harimurti } \\
\text { Yudhoyono dan Sylviana } \\
\text { Murni }\end{array}$ & $\begin{array}{l}\text { PAN, PKB, PPP) } \\
\text { PAsi partai (Demokrat, }\end{array}$ & 28 Kursi \\
\hline $\begin{array}{l}\text { Basuki Tjahaja Purnama } \\
\text { (Ahok) dan Djarot Saiful } \\
\text { Hidayat }\end{array}$ & $\begin{array}{l}\text { Hanura, Nasdem, Golkar) } \\
\text { Hasied partai (PDIP, }\end{array}$ & 52 Kursi \\
\hline $\begin{array}{l}\text { Anies Baswedan dan } \\
\text { Sandiaga Uno }\end{array}$ & $\begin{array}{l}\text { 2 koalisi partai (Gerindra } \\
\text { dan PKS) }\end{array}$ & 26 Kursi \\
\hline
\end{tabular}


Pilkada DKI Jakarta 2017 yang diselenggarakan pada 15 Februari 2017 kemudian harus diselenggarakan dalam 2 putaran. Hal ini karena perolehan suara di putaran pertama tidak terdapat satu pun pasangan calon yang memperoleh suara lebih dari 50\%. Pasangan calon yang ditetapkan sebagai kontestan Pilkada putaran kedua adalah pasangan calon peroleh suara terbanyak pertama dan kedua. Pasangan tersebut adalah Ahok-Djarot dan Anies-Sandiaga Uno dengan dukungan koalisi sebagai berikut.

Tabel 3.

Koalisi Partai Pengusung Pasangan Calon Pada Pilkada Putaran Kedua

\begin{tabular}{|l|l|c|}
\hline \multicolumn{1}{|c|}{ Pasangan Calon } & \multicolumn{1}{|c|}{ Koalisi Partai Pengusung } & Jumlah Kursi di DPRD \\
\hline $\begin{array}{l}\text { Basuki Tjahaja Purnama } \\
\text { (Ahok) dan Djarot Saiful }\end{array}$ & $\begin{array}{l}\text { Hanura, Nasdem, Golkar, } \\
\text { Hidayat }\end{array}$ & PPP, PKB) \\
\hline $\begin{array}{l}\text { Anies Baswedan dan } \\
\text { Sandiaga Uno }\end{array}$ & $\begin{array}{l}\text { 3 Partai Koalisi (Gerindra, } \\
\text { PKS, PAN) }\end{array}$ & 28 kursi \\
\hline
\end{tabular}

Sumber data: Diolah oleh peneliti

Pilkada DKI Jakarta 2017 putaran kedua kemudian dimenangkan oleh pasangan Anis-Sandi dengan perolehan suara sebanyak 57,96\% (3.240.987 suara). Sedangkan pasangan Ahok-Djarot memperoleh suara sebanyak 42,04\% (2.350.366). Pada tanggal 10 Oktober 2018, Anis dan Sandi secara resmi dilantik sebagai gubernur dan wakil gubernur DKI Jakarta periode 2017-2022.

Peta koalisi partai dalam mengusung pasangan calon pada Pilkada DKI Jakarta 2017 menunjukkan konfigurasi kekuatan politik yang sangat dinamis. Faktor ideologi dan arah kebijakan partai tidak menjadi pertimbangan utama dalam membentuk koalisi partai. Hal ini ditandai dengan hadirnya koalisi yang terbentuk dari campuran ideologi partai antara nasionalis dan agama pada ketiga koalisi partai di masing-masing pasangan calon. Meskipun pada Pilkada putaran pertama koalisi partai pendukung Ahok-Djarot memperlihatkan hanya diusung oleh partai dengan platform nasionalis tanpa adanya partai dengan platform agama, tetapi pada Pilkada putaran kedua, dua partai Islam (PPP dan PKB) justru beralih dukungan pada pasangan Ahok-Djarot.

Potret peta koalisi partai politik yang terbentuk dari berbagai variasi identitas partai menegaskan bahwa koalisi bersifat cair, dinamis, dan tidak mengutamakan jarak kedekatan ideologi dan garis kebijakan partai. Pola ini sesungguhnya terjadi juga pada 
daerah lain yang mana bentuk koalisi yang dibangun dalam merespon politik elektoral menunjukkan pragmatisme partai politik yang cenderung hanya berorientasi pada office seeking. ${ }^{19}$ Sebagaimana diungkap oleh $\operatorname{Riker}^{20}$ bahwa office seeking mendudukan koalisi partai sebagai entitas tunggal yang sama-sama bertujuan memaksimalkan kekuasaan dengan mengabaikan prinsip perbedaan ideologi dan arah kebijakan partai. Implikasinya dari koalisi yang dinamis ini menyebabkan relasi politik di intra dan inter koalisi partai mengalami kompetisi yang tidak sehat. Pola koalisi yang muncul cenderung lebih mengedepankan ukuran jumlah kursi partai sebagai konsekuensi syarat mengusung calon yang telah ditetapkan oleh Undang-Undang.

Meskipun koalisi partai sangat cair, namun koalisi partai politik yang terbentuk antara PKS dan Gerindra menarik untuk ditelaah lebih lanjut pada pembahasan ini. Pada beberapa kesempatan dan momentum politik, PKS dan Gerinda kompak membangun koalisi untuk mengusung pasangan calon. Paling tidak terlihat dari tiga momentum pemilu yang cukup krusial yaitu Pilpres 2014, Pilpres 2019 dan Pilkada DKI Jakarta 2017. Artinya, secara tidak langsung ada ikatan emosional yang terbangun antara PKS dan Gerindra yang dilandasi oleh kesamaan orientasi politik dalam kontestasi elektoral. Pada Pilkada DKI Jakarta 2017, dua partai ini mengusung pasangan Anis-Sandi. Anis Baswedan bukan kader partai. Ia lebih dikenal sebagai akademisi dan mantan Menteri Pendidikan dan Kebudayaan di awal pemerintahan pertama Joko Widodo. Sementara Sandiaga merupakan pengusaha sekaligus politisi yang baru bergabung ke Gerindra di tahun 2015. Bangunan koalisi antara PKS dan Gerindra diuji menjelang momentum Pilpres 2019.

\section{Pilpres 2019: Dari Koalisi Sampai Kekosongan Kursi Wakil Gubernur}

Kurang dari satu tahun Anis-Sandi memimpin Jakarta, Indonesia tengah bersiap menghadapi pesta demokrasi akbar yaitu Pilpres 2019. Keriuhan Pilpres 2019 sudah terjadi pada tahun-tahun sebelumnya yang ditandai oleh berbagai manuver partai politik dalam membangun konsolidasi dan komunikasi politik untuk mengusung paket

\footnotetext{
${ }^{19}$ Mahpudin, Abdul Hamid \& Shanty Kartika Dewi, "Dinamika Koalisi Partai Politik dalam Pencalonan Kepala Daerah pada Pilkada Banten 2017" dalam Prosiding Seminar Nasional Prodi Ilmu Pemerintahan 2018, Banten, (2018); Luthfi Makhasin, "Orientasi Ideologi dan Pragmatisme Politik Model Pembentukan Koalisi dalam Pilkada Serentak di Jawa Tengah 2015" dalam Jurnal Ilmu Sosial Dan Ilmu Politik, Vol.19, No.3 (2016), h. 234-250.

${ }^{20}$ William Harrison Riker, Loc. Cit.
} 
pasangan calon presiden dan wakil presiden. Pilpres 2019 kembali mengkontestasikan antara Joko Widodo dan Prabowo Subianto yang sebelumnya ke dua nama ini pernah berebut jabatan pada Pilpres 2014. Pada dua momentum Pilpres (2014 dan 2019), PKS dan Gerindra terlihat kompak dan berkomitmen untuk tetap berada dalam barisan koalisi yang sama sebagai berikut.

Tabel 4.

Peta Koalisi Partai pada Pilpres 2014 dan 2019

\begin{tabular}{|c|l|l|}
\hline Tahun & \multicolumn{1}{|c|}{ Pasangan Calon } & \multicolumn{1}{|c|}{ Peta Koalisi } \\
\hline \multirow{2}{*}{2014} & Prabowo Subianto dan Hatta Rajasa & $\begin{array}{l}\text { Gerindra, PAN, PKS, PPP, } \\
\text { Golkar, PBB, Demokrat }\end{array}$ \\
\cline { 2 - 3 } & Joko Widodo dan Jusuf Kalla & $\begin{array}{l}\text { PDIP, PKB, Nasdem, Hanura, } \\
\text { PKPI }\end{array}$ \\
\hline \multirow{2}{*}{2019} & Joko Widodo dan Ma'ruf Amin & $\begin{array}{l}\text { PDIP, Golkar, Nasdem, PPP, } \\
\text { Hanura, PKB }\end{array}$ \\
\cline { 2 - 3 } & Prabowo dan Saniaga Uno & Gerindra, PKS, PAN, Demokrat \\
\hline
\end{tabular}

Sumber data: Diolah oleh peneliti

Kedekatan PKS dan Gerindra terlihat dalam mengusung pasangan calon sebelum pemilu diselenggarakan. Komitmen tersebut tetap terjaga paska pemilu berakhir di saat partai lain mulai bergeser ke kubu pemerintah yang memenangkan kontestasi pemilu. Bisa disebut jika Gerindra dan PKS merupakan partai yang terbilang cukup solid untuk bertahan di garis oposisi. Konsistensi dua partai ini berada di luar koalisi pemerintahan terlihat terjadi di sepanjang masa pemerintahan Joko WidodoKalla periode 2014-2019 hingga pencalonan presiden di tahun 2019. Koalisi Gerindra dan PKS dipandang cukup solid dibandingkan relasi politik dengan partai lain. ${ }^{21} \mathrm{Hal}$ ini membuka peluang yang cukup besar bagi PKS untuk mengajukan calon wakil presiden pendamping Prabowo di Pilpres 2019. Tercatat PKS pernah mengajukan 9 nama yang berasal dari internal kader PKS kepada Prabowo dengan memberi dua opsi: Prabowo memilih satu dari sembilan nama yang diusulkan atau PKS sendiri yang menentukan satu nama tersebut.

Namun proses komunikasi politik antara Gerindra dan PKS tidak mendapatkan titik temu. Prabowo sebagai calon wakil presiden sekaligus ketua umum Partai Gerindra

\section{${ }^{21}$ Ibid.}


tidak menunjukkan ketertarikan dengan nama-nama yang diusulkan oleh PKS. Di sisi lain, nama yang diusulkan oleh PKS tidak memiliki popularitas dan elektabilitas yang besar berdasarkan hasil berbagai lembaga survei. Padahal popularitas dan elektabilitas menjadi hal yang penting untuk suksesi kontestasi electoral. ${ }^{22}$ Akhirnya Prabowo memilih Sandiaga Uno untuk menjadi calon wakil presiden. Pilihan untuk mengusung Sandiaga Uno sangat rasional sebab Sandi adalah seorang pengusaha terkenal sehingga dapat membantu agenda pemenangan pemilu yang memakan anggaran tidak sedikit. Pertimbangan lainnya, Sandi menjabat sebagai wakil gubernur DKI Jakarta sehingga memiliki popularitas dan elektabilitas yang lebih baik dibandingkan dengan sederet nama yang diusulkan PKS. Begitu pula Sandi dianggap mampu merepresentasikan segmentasi kelompok pemilih pemula. ${ }^{23}$ Kendati PKS kecewa dengan keputusan Gerindra, namun PKS tetap berada dalam barisan koalisi bersama Gerindra.

Hadirnya nama Sandiaga Uno sebagai wakil calon presiden mendamping Prabowo yang diusung oleh koalisi Gerindra dan PKS menyebabkan terjadinya kekosongan kursi wakil gubernur DKI Jakarta. Pada 27 Agustus 2018 Sandiaga Uno secara resmi mundur dari jabatannya. Kekosongan kursi wakil gubernur berpengaruh terhadap bangunan koalisi antara Partai Gerindra dan PKS. Kedua partai ini saling berkompromi di satu pihak, tetapi di pihak lain dapat berubah menjadi saling berkompetisi dalam memperebutkan calon pengganti Sandiaga Uno.

\section{Koalisi Gerindra dan PKS: Terbentuknya Coalition Agreement}

Keputusan politik Prabowo dan Partai Gerindra memilih Sandiaga Uno sebagai calon wakil presiden pada Pilpres 2019 telah memutus harapan PKS untuk memiliki calon kandidat yang diusung oleh kader internal partai sehingga dalam catatan penyelenggaraan Pilpres, PKS belum pernah memiliki kader partai yang diusung menjadi calon presiden maupun calon wakil presiden. Koalisi partai pengusung Prabowo dan Sandi menunjukkan betapa Gerindra berperan sebagai veto player dominan dalam menyusun paket pencalonan untuk Pilpres 2019. Hal ini dapat dilihat

\footnotetext{
${ }^{22}$ Feri Agus, "Menimbang Tiga Kandidat Pendamping Prabowo" dalam https://www.cnn indonesia.com/nasional/20180804205256-32-319581/menimbang-tiga-kandidat-pendamping-prabowo diakses 5 Agustus 2018.

${ }^{23}$ BBC news, "Prabowo Tujuk Sandiaga Uno Sebagai Cawapres Karena Percaya Diri?" dalam https://www.bbc.com/indonesia/indonesia-45133067 diakses 9 Agustus 2018.
} 
dari kombinasi pasangan calon yang berasal dari partai yang sama. Prabowo dan Sandiaga Uno adalah kader partai Gerindra. Sebuah komposisi koalisi yang dianggap tidak ideal. Sebab, pada umumnya, bentuk koalisi partai dalam mengusung paket pasangan calon berasal dari partai yang berbeda. Hal ini sebagaimana diungkap oleh Syamsuddin Haris, Pengamat politik LIPI bahwa dalam sebuah koalisi yang ideal dalam proses pencalonan, partai memiliki posisi yang seimbang dan setara sehingga tidak bisa hanya didominasi oleh satu partai. ${ }^{24}$ Padahal, PKS telah berusaha menawarkan banyak kader internal partai yang dianggap potensial untuk menjadi calon wakil presiden, tetapi sama sekali tidak dilirik oleh Prabowo dan Gerindra.

Untuk meminimalisir kekecewaan PKS terhadap Gerindra sekaligus menjaga hubungan koalisi yang baik, ternyata dibalik terpilihnya Sandiaga Uno sebagai calon wakil presiden bukanlah sebuah keputusan politik yang hadir di ruang hampa. Telah terjadi kesepakatan politik antara Gerindra dan PKS yang mana kekosongan kursi wakil gubernur DKI Jakarta selepas ditinggal oleh Sandiaga Uno menjadi jatah PKS. Kontrak politik ini dibuat menjelang pendaftaran calon presiden dan wakil presiden. Hal ini sebagaimana diungkap oleh Triwikasana, anggota Majelis Syura DPP PKS sebagai berikut:

"Kesepakatan Pilpres katanya sudah ada. Termasuk soal wagub DKI. Jadi itu 1 paket, PKS dukung Pak Sandi maju cawapres dan Gerindra dukung kader PKS jadi pengganti Sandiaga di DKI."25

Kontrak politik yang dilakukan oleh Gerindra dan PKS adalah bagian dari kesepakatan koalisi (coalition agreement). Hal ini dianggap penting untuk menghindari perpecahan di internal partai koalisi sehingga bangunan koalisi yang terbentuk tetap bertahan sebab dalam sebuah koalisi seringkali menimbulkan gesekan antar partai karena terdapat benturan kepentingan politik. $^{26}$ Kompromi politik semacam ini dilakukan oleh Gerindra untuk memastikan loyalitas dukungan PKS dalam upaya

\footnotetext{
${ }^{24}$ Reza Jurnaliston, "Mencari Pengganti Sandiaga Uno, Apakah Gerindra Mau PKS Setengah Hati ?” dalam https://nasional.kompas.com/read/2018/09/20/09300681/mencari-pengganti-sandiagaapakah-gerindra-mau-pks-setengah-hati?page=all diakses 20 September 2018.

${ }^{25}$ Clara Maria Tjandra Dewi, "Berebut Kursi Bekas Sandiaga Uno, PKS Ungkit Lagi Janji Prabowo" dalam https://metro.tempo.co/read/1128614/berebut-kursi-bekas-sandiaga-uno-pks-ungkit-lagijanji-prabowo/full\&view=ok diakses 21 September 2018.

${ }^{26}$ Lanny W. Martin \& Georg Vanberg, Loc.Cit.; Baca juga Wolfgang C. Muller \& Thomas M. Meyer, Loc.Cit.
} 
pemenangan Pilpres 2019 sebab apabila PKS sama sekali tidak diuntungkan secara politik dalam sebuah koalisi dengan Gerindra, PKS tidak akan maksimal dalam mendukung pasangan Prabowo dan Sandiaga Uno. ${ }^{27}$ Oleh karena itu, terdapat pertukaran resources dalam relasi koalisi partai antara Gerindra dan PKS. Dengan kata lain, hadirnya pertukaran resources yang saling menguntungkan antar partai koalisi menjadi penentu keberlanjutan bangunan koalisi yang dibentuk oleh partai politik sehingga keberadaan coalition agreement berpengaruh terhadap relasi antara partai koalisi. Hal ini mempertegas bahwa pola koalisi partai antara Gerindra dan PKS ditopang oleh tujuan office seeking bahwa koalisi partai dibentuk sebagai instrumen memaksimalkan kekuasaan (jabatan politik).

Hadirnya kesepakatan politik (agreement coalition) antara Gerindra dan PKS justru mengalami dinamika politik yang begitu kompleks. Agreement coalition ini di satu pihak menjadi pemersatu koalisi partai tetapi di saat yang bersamaan berpotensi memunculkan konflik di internal partai koalisi. Kompleksitas politik ini tidak lepas sebagai implikasi dari konteks Pilpres 2019 yang turut mewarnai diskursus pengisian wakil gubernur pengganti Sandiaga Uno.

Kesepakatan koalisi bahwa Gerindra akan memberikan kewenangan kepada PKS untuk mengganti posisi Sandiaga Uno sebagai wakil gubernur DKI Jakarta adalah sebuah keputusan politik yang sangat beralasan. Sebab, dalam Undang-undang Nomor 10 tahun 2016 tentang Pilkada menyebut bahwa apabila terdapat kekosongan jabatan wakil gubernur (baik karena meninggal maupun mengundurkan diri) dengan sisa jabatan lebih dari 18 bulan, maka partai pengusung memiliki wewenang untuk mengisi kekosongan jabatan tersebut. Undang-undang tersebut menjelaskan bahwa partai pengusung menentukan dua nama calon untuk selanjutnya diajukan ke DPRD untuk memilih satu calon yang akan menjadi calon gubernur definitif. Aturan semacam ini berbeda dengan regulasi sebelumnya bahwa kewenangan mengisi kekosongan wakil gubernur ada di tangan seorang gubernur bukan partai pengusung. Implikasinya, terjadi pergeseran kekuasaan dalam isu pengisian kekosongan wakil kepala daerah yang sebelumnya menjadi domain kuasa kepala daerah berpindah ke partai politik. Dalam konteks kepala daerah yang diusung oleh koalisi partai, maka Undang-undang Nomor

\footnotetext{
${ }^{27}$ Reza Jurnaliston, Loc. Cit.
} 
10 tahun 2016 telah memaksa partai politik untuk melakukan agreement coalition di internal koalisi partai. Dalam hal ini, kesepakatan koalisi yang dimaksud adalah Gerindra menjanjikan bahwa dua nama calon tersebut berasal dari PKS sehingga dapat dipastikan pengganti Sandiaga berasal dari kader PKS.

Namun dalam perjalanannya, Gerindra mulai menunjukkan tanda-tanda melanggar agreement coalition yang telah dibangun. Diam-diam Gerindra masih mengharapkan kursi wakil gubernur DKI Jakarta agar dapat diisi oleh calon yang berasal dari Gerindra dengan dalih bahwa Sandiaga Uno merupakan kader Partai Gerindra, maka Gerindra yang berhak menentukan pengganti Sandiaga Uno ${ }^{28}$. Hal ini menyebabkan hubungan koalisi Gerindra dan PKS memanas. Kedua partai tersebut bersaing dalam memperebutkan jabatan wakil gubernur. Implikasinya, di dalam internal koalisi partai secara bersamaan terjadi kompromi dan kompetisi dalam memperebutkan akses terhadap kekuasaan. Konteks Pilpres 2019 turut mempengaruhi pilihan politik koalisi partai untuk berkompromi maupun berkompetisi. Hal ini senada dengan argumen Spoon \& Kluver $^{29}$ bahwa konteks politik elektoral berpengaruh terhadap respon partai politik.

Dalam merespon suksesi pemenangan Prabowo dan Sandiaga Uno pada Pilpres 2019, Partai Gerindra dan PKS berusaha menampilkan image ke publik bahwa koalisi mereka kompak. Oleh karena itu, kedua partai ini berkompromi untuk saling mengurangi tensi persaingan politik dalam memperebutkan jabatan wakil gubernur. Hal ini dapat terlihat dari strategi kedua partai ini untuk fokus memenangkan PrabowoSandi namun di saat yang bersamaan tidak terlalu memberi atensi yang terlalu besar dalam isu kekosongan wakil gubernur. Pilihan berkompromi menjadi keputusan politik yang rasional bagi Gerindra dan PKS sebab apabila kedua partai ini berkonflik akan berdampak pada Pilpres 2019. Hal ini menyebabkan selama lebih dari satu tahun, DKI Jakarta belum memiliki wakil gubernur. ${ }^{30}$

\footnotetext{
${ }^{28}$ Nursita Sari, "Ribet Banget Drama Gerindra dan PKS Pilih Wagub" dalam https:// megapolitan.kompas.com/read/2020/01/21/09571441/ribet-banget-drama-gerindra-dan-pks-pilih-wagub?page=all diakses 21 Januari 2020.

${ }^{29}$ Jae-Jae Spoon \& Heike Kluver, "Do Parties Respond ? How Electoral Context Influences Party Responsiveness" dalam Electoral Studies, Vol.35, No. C (2014), h. 48-60.

${ }^{30}$ Ibad Durohman, "Tarian Poco-Poco Wagub Ibu Kota" dalam https://news.detik.com/x/detail/ investigasi/20190904/Tarian-Poco-poco-Wagub-Ibu-Kota/ diakses 4 September 2019.
} 
Kendati demikian, selama kontestasi Pilpres 2019 berjalan, PKS terus berusaha melakukan manuver politik dan menekan Gerindra agar segara menyetujui dua nama calon yang direkomendasikan oleh PKS sesuai dengan kesepakatan bersama. Awalnya PKS telah merekomendasikan tiga nama untuk disetujui oleh Gerindra yaitu Ahmad Syaikhu, Agung Yulianto, dan Abdurrahman Suhaimi. Tetapi Gerindra cenderung mengulur waktu dengan berbagai alasan salah satunya Gerindra merasa belum cocok dengan nama yang direkomendasikan PKS. Bahkan Gerindra justru memunculkan nama Muhammad Taufik, Ketua DPD Gerindra DKI Jakarta sebagai calon yang diusung menggantikan Sandiaga Uno. Sikap Gerindra tersebut menjadi titik awal pelanggaran terhadap coalition agreement yang telah disepakati. Merespon sikap Gerindra yang tidak tegas, PKS mengancam Gerindra akan menarik dukungan terhadap PrabowoSandi dalam Pilpres 2019. ${ }^{31}$

Merespon ancaman PKS, Gerindra akhirnya melakukan kompromi dengan PKS pada tanggal 5 November 2018. Hasil kompromi tersebut Gerindra akan menyetujui rekomendasi nama yang diusulkan oleh PKS dengan syarat harus melalui uji kelayakan dan kepatutan. Syarat tersebut disetujui oleh PKS. Padahal syarat tersebut tidak diatur dalam Undang-undang. Hal ini menunjukkan bahwa syarat uji kelayakan dan kepatutan yang dilakukan oleh partai politik pengusung untuk menentukan dua nama calon wakil gubernur bersifat kesepakatan informal di antara partai koalisi.

Tim panitia uji kelayakan dan kepatutan calon wakil gubernur DKI ditetapkan oleh PKS. PKS menunjuk Syakir Purnomo (Ketua DPW PKS DKI Jakarta) dan Abdurrahman Suhaimi (Fraksi PKS DPRD DKI Jakarta) sebagai panitia tim. Sementara Gerindra menunjuk Siti Zuhro (Peneliti LIPI) sebagai penguji. Pasca uji kelayakan dan kepatutan, Gerindra dan PKS bersepakat memilih dua nama calon wakil gubernur DKI Jakarta dari PKS yaitu Ahmad Syaikhu dan Agung Yulianto. ${ }^{32}$ Dua nama ini kemudian akan diserahkan kepada DPRD DKI Jakarta untuk dipilih satu nama melalui sidang paripurna. Namun polemik antara Gerindra dan PKS belum usai. Dua nama tersebut tidak mendapat rekomendasi dari DPP Gerindra yaitu Prabowo Subianto selaku Ketua Umum Gerindra dan Ahmad Muzani sebagai Sekjen Gerindra. PKS terus menekan Gerindra agar segara menyetujui dua nama calon yang telah disepakati berdasarkan

\footnotetext{
${ }^{31}$ Ibid.

${ }^{32}$ Ibid.
} 
hasil uji kepatutan dan kelayakan. Tekanan politik yang dilakukan oleh PKS berhasil mendapatkan rekomendasi dari Gerindra. Sikap politik Gerindra yang demikian semakin mempertegas bahwa Gerindra tidak komitmen dengan coalition agreement yang telah disepakati sebab Gerindra masih menginginkan agar kursi wakil gubernur DKI Jakarta tetap diisi oleh kader Gerindra. Namun keinginan tersebut perlu menggunakan strategi politik yang tepat agar relasi politik dengan PKS sebagai koalisi partai tetap terjaga terlebih lagi kontestasi Pilpres 2019 masih berlangsung. Salah satu strategi politik yang dilakukan oleh Gerindra adalah dengan menunda-nunda (mempersulit) untuk menyetujui nama calon wakil pengganti Sandiaga Uno yang berasal dari PKS.

Setelah Gerindra dan PKS sebagai partai pengusung menyetujui dua nama calon wakil yang berasal dari PKS, langkah selanjutnya adalah menyerahkan dua nama tersebut kepada DPRD DKI Jakarta untuk dipilih satu nama sebagai wakil gubernur DKI definitif melalui sidang paripurna. Sebelum sidang paripurna, DPRD DKI Jakarta harus membentuk panitia khusus (Pansus) bertugas mengatur proses pemilihan calon wakil gubernur termasuk di dalamnya membuat tata tertib pemilihan. Dari sini, langkah PKS untuk merebut kursi wakil gubernur DKI juga mengalami berbagai kendala. Pasalnya, DPRD tidak segara membentuk Pansus dengan alasan selalu tidak kuorum. Di sisi lain, Gerindra cenderung diam tanpa membantu PKS untuk melakukan lobby politik terhadap anggota DPRD. Padahal sebagai koalisi partai pengusung, Gerindra seharusnya kooperatif dan berpihak pada PKS. Proses pembentukan Pansus masih menggantung tanpa ada kejelasan. Hal ini menegaskan bahwa PKS menghadapi dua tantangan dalam memperjuangkan kader partai untuk menempati posisi wakil gubernur DKI Jakarta. Pertama, di arena internal koalisi dengan Gerindra. Kedua, di arena DPRD dengan partai-partai non pengusung.

Lambannya DPRD mengadakan sidang paripurna dalam menentukan satu dari dua nama calon yang direkomendasikan oleh partai koalisi pengusung tidak lepas dari peta kekuatan partai koalisi yang terbentuk di DPRD dan konteks Pilpres 2019 yang sedang berlangsung. Sebagaimana diketahui, peta koalisi DKI Jakarta sama dengan peta koalisi di Pilpres 2019. Di DPRD, jumlah akumulasi kursi koalisi partai Gerindra dan PKS hanya 26 (24\%) dari 106 jumlah kursi keseluruhan. Artinya, koalisi Gerindra dan PKS sebagai partai pengusung di DPRD adalah minoritas sehingga akan menyulitkan 
untuk proses negosiasi politik dalam menekan diselenggarakannya rapat paripurna. Apalagi Gerindra sendiri tidak sehaluan dengan PKS. Partai non pengusung di DPRD berkepentingan dalam isu kekosongan kursi wakil gubernur sebab secara tidak langsung akan berpengaruh terhadap Pilpres 2019. Apabila kursi wakil gubernur segera terisi dari partai koalisi Gerindra dan PKS di tengah Pilpres 2019 yang sedang berlangsung akan memberi political benefit kepada Gerindra dan PKS yang mengusung Prabowo dan Sandiaga Uno pada Pilpres 2019, sementara partai non pengusung Anies-Sandi adalah mayoritas pengusung pasangan Joko Widodo dan Maruf Amin.

Peta politik DKI sangat strategis sebab menjadi barometer politik nasional di samping jumlah pemilih DKI termasuk besar mencapai lebih dari 7 juta pemilih. Oleh karena itu, pilihan untuk menunda-nunda dilaksanakannya sidang paripurna di DPRD sangat beralasan berkaitan dengan kontestasi Pilpres 2019. Artinya, kontestasi dalam memperebutkan kursi DKI Jakarta tidak semata-mata pertarungan politik di antara partai koalisi yaitu Gerindra dan PKS tetapi juga di arena DPRD. Oleh karena itu, kompromi dan kompetisi partai berlangsung pada dua arena sekaligus yaitu di internal partai koalisi dan di arena DPRD. Hal ini dipertegas dengan kenyataan bahwa DPRD belum melakukan sidang paripurna hingga Pilpres 2019 berakhir yang kemudian berdampak pada belum terisinya kursi wakil gubernur DKI Jakarta.

\section{Berebut Kursi Wakil Gubernur: Akhir Koalisi Gerindra dan PKS}

Meskipun di atas kertas Gerindra dan PKS sudah memiliki dua nama calon dari kader PKS dan telah direkomendasikan ke DPRD untuk dilaksanakan sidang paripurna, tetapi Jakarta masih belum memiliki wakil gubernur selama lebih dari satu tahun sejak ditinggalkan oleh Sandiaga Uno. Hal ini tidak lepas karena efek Pilpres 2019 sebagaimana diulas pada pembahasan sebelumnya. Oleh karena itu, selama Pilpres berlangsung, DPRD belum juga melakukan sidang paripurna dan isu terkait kekosongan kursi wakil gubernur di DKI Jakarta seolah tenggelam oleh hiruk-pikuk perpolitikan nasional terkait Pilpres 2019. Meskipun selama periode waktu tersebut, PKS terus melakukan lobby politik di DPRD, tetapi hasilnya nihil. Sementara Gerinda dan PKS terus berusaha tampil solid dalam proses pemenangan Pilpres 2019 yang mengusung Prabowo dan Sandiaga Uno meskipun di antara mereka tersimpan konflik politik perihal sikap Gerindra yang tidak komitmen merealisasikan coalition agreement. 
Paska kontestasi Pilpres berakhir, isu mengenai kekosongan wakil gubernur DKI kembali diperdebatkan. Hal tersebut disebabkan karena konteks Pilpres 2019 tidak lagi banyak memberi pengaruh dalam relasi antara Gerindra dan PKS sebagai partai koalisi termasuk partai politik di DPRD Jakarta. Pilpres 2019 dimenangkan oleh Pasangan Jokowi dan Maruf Amin. Merespon kekalahan ini, Gerindra kemudian berpindah haluan dari PKS dengan bergabung ke koalisi partai pengusung Jokowi-Amin. Sebagai imbalannya, Gerinda mendapat 2 jatah kursi menteri yaitu Kementerian Perikanan dan Kementerian Pertahanan yang langsung dipegang oleh Prabowo Subianto. Dengan demikian, koalisi yang dibangun antara Gerindra dan PKS di tingkat nasional telah bubar. Hal ini berdampak pula pada relasi politik kedua partai ini sebagai koalisi pengusung pemerintah DKI Jakarta. Meski secara normatif, dua partai ini tetap sebagai koalisi partai pengusung Anis Baswedan dan Sandiaga Uno. Tetapi paska Pilpres 2019 dan masuknya Gerindra di koalisi pemerintah di tingkat nasional turut mempengaruhi peta persaingan politik dalam berebut kekosongan kursi wakil gubernur.

Selain itu, Pilpres 2019 diselenggarakan berbarengan dengan pemilu lainnya yaitu pemilihan DPR RI, DPD RI, DPRD Provinsi dan DPRD Kabupaten/kota. Implikasinya terjadi perubahan peta politik di DPRD DKI Jakarta bersamaan dengan berubahnya formasi anggota dewan yang terlibat di dalamnya. Isu kekosongan wakil gubernur gagal diselesaikan oleh DPRD DKI Jakarta periode 2014-2019 karena polemik yang berlarut di internal partai pengusung antara Gerindra dan PKS dan efek Pilpres 2019 serta fokus anggota dewan dalam suksesi pemenangan Pileg DPRD DKI Jakarta untuk periode 2019-2014. Oleh karena itu, isu kekosongan jabatan wakil gubernur DKI Jakarta menjadi domain anggota DPRD periode 2019-2024. Berikut peta kekuatan partai politik di DPRD DKI Jakarta periode 2019-2024.

Tabel 5.

Peta kekuatan Partai Politik di DPRD DKI Jakarta Periode 2019-2024

\begin{tabular}{|l|c|}
\hline \multicolumn{1}{|c|}{ Partai } & Kursi \\
\hline PDIP & 25 \\
\hline Gerindra & 19 \\
\hline PKS & 16 \\
\hline Demokrat & 10 \\
\hline PAN & 9 \\
\hline PSI & 8 \\
\hline
\end{tabular}




\begin{tabular}{|l|c|}
\hline Nasdem & 7 \\
\hline Golkar & 6 \\
\hline PKB & 5 \\
\hline PPP & 1 \\
\hline Jumlah Kursi & 106 \\
\hline
\end{tabular}

Sumber data diolah oleh Peneliti

Di tengah ketidakpastian sidang paripurna yang cukup lama, Gerindra melakukan manuver politik kepada DPRD untuk memastikan bahwa figur yang akan menggantikan Sandiaga Uno dari kader Gerindra bukan PKS. Oleh karena itu, ketidakjelasan kelanjutan sidang paripurna di DPRD dijadikan sebagai momentum bagi Gerindra untuk menganulir dua nama calon wakil gubernur dari PKS yang sebelumnya sudah disepakati Gerindra berdasarkan hasil uji kelayakan dan kepatutan, bahkan dua nama tersebut telah diserahkan ke DPRD. Gerindra melakukan lobby politik kepada partai non pengusung di DPRD tidak dalam konteks mendukung PKS, tetapi memiliki agenda politik lain yaitu mengajukan nama calon wakil gubernur dari Gerindra. Hal ini sebagaimana penyataan Iman Satria, anggota Fraksi Gerindra DPRD DKI yang menilai bahwa Sandiaga Uno berasal dari Gerindra maka figur yang tepat menggantikan Sandi harus berasal dari Gerindra. Selain itu, Satria juga menyebut bahwa partai pengusung pemerintah DKI Jakarta berasal dari koalisi partai Gerindra dan PKS, maka dua nama calon yang direkomendasikan ke DPRD seharusnya berasal dari Gerindra dan PKS bukan dua-duanya berasal dari PKS. ${ }^{33}$

Berkaitan dengan komitmen Gerindra soal coalition agreement, Satria menampik bahwa saat itu, Prabowo menyebut sebatas jatah calon bukan berarti jabatan wakil gubernur pengganti Sandi harus dari PKS sebab Prabowo tidak dapat menjamin hal tersebut karena menjadi wewenang DPRD bukan partai Gerindra. ${ }^{34}$ Hal ini sangat bertolak belakang dengan sikap Gerindra di awal pencalonan Pilpres 2019 yang menjamin bahwa PKS akan menggantikan Sandiaga Uno sebagai kompensasi atas kegagalan PKS mengusung calon dari kader internal partai pada Pilpres 2019. Sebagaimana diungkap oleh Fadli Zon, Wakil Ketua Umum Partai Gerindra.

\footnotetext{
${ }^{33}$ Ibid.
}

${ }^{34}$ Ibid. 
"Calon wakil gubernurnya pengganti Pak Sandiaga itu, sesuai kesepakatan dari partai-partai pengusung itu adalah kader PKS." 35

Sikap Gerindra menunjukkan bahwa partai berlambang burung garuda tersebut menginginkan jabatan wakil gubernur dan berupaya melanggar coalition agreement. Dampaknya, terdapat kompetisi di internal partai koalisi dalam berebut kursi wakil gubernur. Hal ini dipertegas oleh pernyataan Ketua Fraksi DPRD DKI Jakarta, Gembong Warsono sebagai berikut:

"Masalah Wagub Jakarta belum kelar karena belum sepakatl soal kandidat antara PKS dan Gerindra, bukan soal mandeknya pembahasan di DPRD. Mereka terlalu lama tidak bersepakat soal dua nama yang muncul. Dan ketika dikirim ke DPRD, kan belum sepakat juga. Makanya soal wagub itu kuncinya ada di dua partai pengusung itu. Partai lain hanya pasif menunggu." 36

Karena tidak ada kejelasan dari DPRD, PKS kemudian mengusulkan dua nama calon alternatif kepada Gerindra yaitu Adhyaksa Dault (mantan Menteri Pemuda dan Olahraga) dan Nurmansjah Lubis (mantan anggota DPRD DKI Jakarta Periode 20092014) sebagai upaya negosiasi politik agar Gerindra menyetujui rekomendasi nama calon dari PKS. Tetapi Gerindra sama sekali tidak memberikan respon terhadap usulan alternatif PKS. Akhirnya, PKS memutuskan kembali pada dua nama calon yang sudah disepakati sebelumnya yaitu Syaikhu dan Agung. Di saat yang bersamaan, Gerindra mengusulkan empat nama calon yaitu Ferry J Yuliantono (Wakil Ketua Umum Gerindra), Ahmad Riza Patria (Ketua DPP Gerindra), Arnes Lukman (anggota Dewan Penasihat Gerindra) dan Saefullah (Sekretaris Daerah DKI Jakarta). ${ }^{37}$ Merespon hal tersebut, PKS merasa dikhianati oleh Gerindra. Implikasinya, hubungan kedua partai sebagai partai koalisi yang cukup solid mulai menunjukkan keretakan.

Masing-masing partai koalisi pengusung (Gerindra dan PKS) memiliki nama calon yang diunggulkan. Namun proses politik di DPRD masih mandeg. DPRD belum juga melaksanakan sidang paripurna untuk pemilihan wakil gubernur. DPRD yang baru terpilih pada Pileg 2019 masih fokus pada pembahasan yang lain seperti pembentukan

\footnotetext{
${ }^{35}$ Hendro, "Sesuai Kesepakatan Pengganti Sandiaga Uno Adalah Kader PKS" dalam https:// indonews.id/artikel/15121/Sesuai-Kesepakatan-Pengganti-Sandiaga-Uno-Adalah-Kader-PKS/ diakses 10 Agustus 2018.

${ }^{36}$ Ibad Durohman, Loc.Cit.

${ }^{37}$ Nursita Sari, Loc.Cit.
} 
alat kelengkapan dewan dan membahas anggaran untuk tahun 2020. Karena tidak ada kejelasan di DPRD, akhirnya PKS dan Gerindra kembali melakukan kesepakatan politik (coalition agreement). Kedua partai bersepakat bahwa dua nama calon wakil gubernur berasal dari Gerindra dan PKS. Artinya Gerindra dan PKS masing-masing mengusulkan satu nama calon. Coalition agreement yang kedua ini pada dasarnya sebagai upaya mencari solusi dari kebuntuan Gerindra dan PKS dengan melanggar kesepakatan politik sebelumnya. Padahal, coalition agreement di awal, Gerinda memberikan jatah kursi wakil gubernur kepada PKS, artinya dua nama calon yang direkomendasikan ke DPRD berasal dari PKS. Implikasinya, kembali terjadi perombakan nama bakal calon. Calon dari Gerindra adalah Ahmad Riza Patria sementara dari PKS adalah Nurmansjah Lubis. Kedua nama calon ini tertuang dalam surat keputusan yang telah disetujui dan ditandatangani oleh pimpinan tertinggi kedua partai politik sebagai partai koalisi pengusung. Di pihak Gerindra, yang mendatangani surat keputusan itu adalah Prabowo Subianto (Ketua Umum Partai Gerindra), Ahmad Muzani (Sekretaris Jenderal Gerindra, Mohamad Taufik (Ketua DPD Gerindra DKI Jakarta), dan Husni Thamrin (Sekretaris DPD Gerindra DKI Jakarta). Sementara di pihak PKS, yang menandatangani surat keputusan tersebut adalah Sohibul Iman (Presiden PKS), Mustafa Kamal (sekretaris Jenderal PKS), Sahir Purnomo (Ketua DPW PKS DKI Jakarta), dan Agung Yulianto (Sekretaris Umum DPW DKI Jakarta). ${ }^{38}$

Dua nama ini kemudian di serahkan kepada Gubernur DKI Jakarta, Anies Baswedan untuk selanjutnya diserahkan ke DPRD. Artinya bola panas saat ini terdapat ada di DPRD. Implikasinya, kompetisi dan kompromi politik tidak hanya melibatkan Gerindra dan PKS sebagai partai pengusung tetapi juga melibatkan partai politik non pengusung di DPRD. Gerindra dan PKS sama-sama melakukan manuver politik, melobby anggota dewan di DPRD agar mendapatkan dukungan suara. Sebab, DPRD berwenang menentukan satu dari dua nama calon yang diusulkan oleh partai pengusung melalui sidang paripurna. Hal ini senada dengan yang disampaikan oleh salah satu anggota DPRD DKI Jakarta Fraksi Nasdem, Bestari Barus sebagai berikut:

"Persaingan di DPRD bakal berlangsung "ramai" jika Partai Gerindra dan PKS mengajukan nama kader masing-masing. Ada kemungkinan lobi-lobi kepada

${ }^{38}$ Ibid. 
fraksi di DPRD makin intens untuk mengamankan nama-nama kader itu bisa meraih suara mayoritas anggota dewan." 39

Di lain pihak, proses pengisian jabatan yang berlarut-larut menyebabkan kegiatan sidang paripurna harus segara dijalankan. Sebab regulasi mengatur bahwa kekosongan wakil gubernur dapat disisi dengan syarat sisa jabatan minimal 18 bulan. Sementara pasca Pilpres, kursi wakil gubernur masih belum terisi karena konflik antara Gerindra dan PKS yang berlarut-larut. Oleh karena itu, pada April 2020, sidang paripurna harus diselenggarakan apabila tidak, maka DKI Jakarta terancam tidak akan memiliki wakil gubernur hingga Pilkada berikutnya. Akhirnya DPRD mulai membahas sidang paripurna pada awal tahun 2020. Masa ini menjadi babak penting sebagai peluang bagi Gerindra dan PKS untuk melakukan lobby politik di DPRD. Kekuatan lobby politik akan sangat menentukan calon mana yang akan terpilih menjadi wakil gubernur. Menurut Adi Prayitno, Pengamat Politik UIN Syarief Hidayatullah ${ }^{40}$, di atas kertas Gerindra lebih unggul dibandingkan PKS sehingga peluang Gerindra memenangkan pertarungan di DPRD akan berhasil. Hal ini dilihat dari dua hal: pertama, dua nama calon (Agung Yulianto dan Ahmad Syaikhu) yang pernah diusulkan oleh PKS ditolak Gerindra dan memaksa PKS mengganti alternatif nama lain.

Kedua, Di DPRD, langkah politik Gerindra lebih luwes dibandingkan PKS. Sejak Gerindra bergabung dengan partai koalisi pemerintah di tingkat nasional pasca Pilpres 2019, peta koalisi di DKI Jakarta cenderung lebih cair yang mana Gerinda merasa memiliki kedekatan dengan partai non pengusung Anis-Sandi sehingga dapat memudahkan proses lobby politik di DPRD, hal yang sulit di lakukan oleh PKS karena masih berada di kubu yang berbeda baik di DKI Jakarta maupun di tingkat nasional. Hal ini terbukti misalnya dua nama calon dari PKS yang sempat diserahkan ke DPRD tidak mendapat respon positif dari partai non pengusung Anis-Sandi di DPRD yang berujung pada berlarutnya proses pembentukan panitia pemilihan, misalnya PDIP, PKB, PSI, Nasdem, PPP, dan Golkar ${ }^{41}$. Partai-partai ini merupakan koalisi partai pendukung

\footnotetext{
${ }^{39}$ Hendra Friana, "Kader Gerindra dan PKS Saling Kunci Demi Mendampingi Anies Baswedan" dalam https://tirto.id/kader-gerindra-dan-pks-saling-kunci-demi-mendampingi-anies-baswedan-cV9f diakses 31 Agustus 2018.

${ }^{40} J u l i$ Hantoro, “Ahmad Riza Patria Wagub, Pengamat: Kekuatan Lobi Gerindra” dalam https:// metro.tempo.co/amp/1328457/ahmad-riza-patria-wagub--pengamat-kekuatan-lobo-gerindra diakses 6 April 2020.

${ }^{41}$ Ibid.
} 
Jokowi yang kemudian dimanfaatkan oleh Gerindra untuk melakukan lobby-lobby politik karena merasa bagian dari koalisi pemerintahan Jokowi. Hal ini menegaskan bahwa persaingan Gerindra dan PKS sesungguhnya tidak terletak pada figur yang dicalonkan melainkan bergantung pada kekuatan kompromi politik di DPRD.

Sidang Paripurna pemilihan calon wakil gubernur akhirnya diselenggarakan pada 6 April 2020 di tengah situasi pandemi covid-19. Pemilihan tersebut dihadiri oleh 100 anggota DPRD dari 106 jumlah keseluruhan anggota DPRD DKI Jakarta. Hasil pemilihan menunjukkan kemenangan bagi Ahmad Riza Patria dari Gerindra dengan mendapat sebanyak 81 suara. Sementara Nurmansyah, calon dari PKS hanya mendapat 17 suara. Dua suara lainnya dianggap tidak $\mathrm{sah}^{42}$. Hasil ini mempertegas bahwa Gerinda sukses melakukan negosiasi politik terhadap partai-partai non pengusung Anis-Sandi dengan mendominasi mayoritas dukungan DPRD. Meskipun kita tidak dapat mengetahui secara pasti berasal dari partai mana suara yang diperoleh kedua nama calon tersebut, tetapi merujuk pada peta kekuatan partai politik di DPRD berdasarkan jumlah kursi yang ada di DPRD DKI Jakarta periode 2019-2024 (sebagaimana tersaji pada tabel 5), maka dapat diambil kesimpulan bahwa PKS yang mendapat sebanyak 17 suara berasal dari anggota dewan PKS yang berjumlah 16 orang ditambah satu suara dari partai lain. Sebagaimana diketahui, jumlah kursi PKS di DPRD sebanyak 16 kursi. Sementara suara dari partai lainnya berhasil direbut oleh Gerindra. Berkaca pada hasil tersebut, PKS harus merelakan jabatan wakil gubernur DKI Jakarta kembali direbut oleh Gerindra dan di saat yang bersamaan PKS telah dikhianati oleh Gerindra karena melanggar coalition agreement. Hal ini menyebabkan bangunan koalisi PKS dan Gerindra yang telah dibangun cukup lama dan solid telah berakhir. ${ }^{43}$ Di tingkat nasional sejak Gerindra memutuskan bergabung dengan pemerintahan Jokowi, sementara di DKI sejak Gerindra merebut jatah kursi wakil gubernur yang seharusnya menjadi peluang PKS.

\footnotetext{
${ }^{42}$ Riyan Setiawan, "Menang Telak, Riza Patria Terpilih Sebagai Wagub Jakarta" dalam https://tirto.id/menang-telak-riza-patria-terpilih-sebagai-wagub--jakarta-eLjv diakses 6 April 2020.

${ }^{43}$ Iqbal S. Nugroho, "Gerindra dan PKS Resmi Bercerai" dalam https://www.merdeka.com/ politik/gerindra-dan-pks-resmi-cerai.html?page=all diakses 21 Februari 2020.
} 


\section{Kompetisi, Kompromi, Coalition Agreement: Sebuah Pragmatisme Partai}

Terpilihnya Riza Patria sebagai wakil gubernur DKI Jakarta dari kader Partai Gerindra telah mengakhiri pertarungan politik antara Gerindra dan PKS dalam memperebutkan kursi wakil gubernur. Artikel ini menunjukkan bahwa dalam sebuah koalisi ternyata partai tetap bersaing dalam merebut dan mempertahankan kekuasaan. Persaingan tersebut lebih berorientasi pada office seeking dibandingkan policy seeking. Meskipun didominasi oleh persaingan, tetapi pada kesempatan politik tertentu, persaingan tersebut dibalut oleh kompromi sebagaimana yang diperlihatkan oleh Gerindra dan PKS yang membuat coalition agreement terkait kekosongan wakil gubernur. Coalition agreement adalah produk dari kompromi partai yang berperan dalam menjaga dan memelihara relasi antar partai koalisi. Implikasinya, ketika coalition agreement ini tidak bekerja, maka bangunan koalisi yang terjalin menjadi hancur.

Relasi politik antara Gerindra dan PKS sebagai partai koalisi dalam konteks berebut wakil gubernur DKI Jakarta di tengah Pilpres 2019 menyebabkan hubungan relasi kedua partai ini menjadi kompleks. Implikasinya, Gerindra dan PKS harus menjalankan dua logika yang saling berkontestasi. Di satu sisi, Gerindra dan PKS harus menunjukkan sikap berkompromi untuk kepentingan suksesi Pilpres 2019. Di sisi yang lain, dua partai ini bersaing satu sama lain dalam berebut kursi wakil gubernur. Persaingan politik semakin terasa menguat setelah Pilpres 2019 selesai dan Gerindra bergabung ke kubu koalisi partai pendukung pemerintah Jokowi. Menariknya, persaingan ini ternyata tidak hanya melibatkan kedua partai tersebut, tetapi bergeser ke arena DPRD (partai politik non pengusung Anis-Sandi). Persaingan antara Gerindra dan PKS memaksa mereka untuk berkompromi dengan partai lain. Dengan kata lain, kompetisi dan kompromi partai berlangsung dalam arena intra dan inter koalisi partai.

Relasi koalisi Gerindra dan PKS menegaskan bahwa pilihan kompetisi dan kompromi sangat cair sehingga tidak dapat didikotomikan secara jelas. Pilihan partai apakah harus berkompetisi atau berkompromi bergantung pada kepentingan politik apa yang sedang dipertahankan atau ingin direbut. Hal ini berdampak pada cairnya bangunan koalisi partai sekaligus menunjukkan kerapuhan. Ketika partai masih mendapat political benefit dari hubungan koalisi, maka koalisi tetap bertahan. Sebaliknya, apabila koalisi tidak memberikan political benefit tertentu, maka saat itu 
pula koalisi bubar. Kenyataan ini seolah membenarkan sebuah ungkapan bahwa dalam arena politik "tidak ada kawan yang abadi, yang ada kepentingan yang abadi”.

Diskursus tentang perebutan kursi wakil gubernur menempatkan partai sebagai pemilik kuasa dalam menentukan calon yang akan mengisi jabatan tersebut. Partai menjadi pragmatis sebab hanya mempertimbangkan soal siapa partai yang berhak mengajukan nama calon. Hal yang absen adalah perdebatan soal bagaimana kualitas, kapabilitas, rekan jejak calon yang akan mengisi jabatan wakil gubernur. Dalam konteks DKI Jakarta dengan segudang permasalahan ibukota tentu diperlukan figur yang benarbenar memahami persoalan khas Jakarta seperti kemacetan, banjir, polusi, ketimpangan dan seterusnya. Tetapi ternyata kita hanya disuguhkan soal kompetisi dan kompromi partai yang beradu kuat melakukan negosiasi politik untuk mengamankan jabatan.

\section{Kesimpulan}

Artikel ini mengungkap bagaimana kompetisi dan kompromi terjadi dalam koalisi partai antara Gerindra dan PKS dalam memperebutkan kekosongan kursi wakil gubernur DKI Jakarta. Konteks Pilpres 2019 turut mempengaruhi relasi politik di antara ke dua partai tersebut. Pilihan untuk berkompetisi dan berkompromi berimplikasi pada hadirnya kontrak politik antara partai koalisi (coalition agreement) yang dibuat oleh Gerindra dan PKS. Bahwa Gerindra memberikan kesempatan kepada kader dari PKS untuk menggantikan Sandiaga Uno yang sebelumnya menjabat sebagai wakil gubernur DKI Jakarta sebagai bentuk kompensasi politik atas dukungan PKS terhadap PrabowoSandiaga Uno sebagai pasangan calon presiden dan wakil presiden pada Pilpres 2019. Terdapat kesamaan peta koalisi di tingkat lokal (Jakarta) dan nasional, sehingga isu politik di lokal maupun nasional turut mempengaruhi dinamika politik di internal koalisi termasuk relasi dengan partai lain non koalisi.

Hadirnya coalition agreement ini menyebabkan partai koalisi (Gerindra dan PKS) harus mendamaikan dua logika yang saling bersaing. Di satu sisi, mereka harus menunjukkan persatuan saat Pilpres 2019, tetapi di saat yang bersamaan mereka bersaing dalam memperebutkan pengisian jabatan wakil gubernur. Dua logika yang saling bersaing tersebut menyebabkan partai koalisi berkompetisi sekaligus berkompromi. Konteks Pilpres 2019 membentuk perilaku partai koalisi yang menjelaskan kapan mereka berkompetisi dan berkompromi. Kompetisi dan kompromi 
partai berlangsung dalam arena intra dan inter koalisi partai. Pada mulanya, coalition agreement ini menjadi perekat koalisi, namun di akhir (pasca Pilpres 2019) menjadi penyebab hancurnya koalisi karena Gerindra tidak komitmen dengan coalition agreement tersebut. Relasi Gerindra dan PKS dalam sebuah koalisi yang saling bersaing dan berkompromi dalam memperebutkan kursi wakil gubernur menunjukkan bahwa koalisi yang dibangun tidak berorientasi pada isu-isu kebijakan, melainkan lebih berpijak pada kepentingan kekuasaan.

\section{DAFTAR PUSTAKA}

Albala, Adrian. "When Do Coalitions Form Under Presidentialism, and Why Does It Matter? A Configurational Analysis From Latin America" dalam Politics, Vol. 41, No.3 (2021), h. 351-370.

Ambardi, Kuskridho. Mengungkap Politik Kartel: Studi Tentang Sistem Kepartaian di Indonesia Era Reformasi. Jakarta: Kepustakaan Populer Gramedia, 2009.

Back, Hanna, Marc Debus \& Patrick Dumont. "Who Gets What in Coalition Governments? Predictors of Portfolio Allocation in Parliamentary Democracies" dalam European Journal of Political Research, Vol.50 (2011), h. 441-478.

Bradshaw, Gavin \& Ntsikelelo Breakfast, "Mediating Coalition Politics at The Local Goverment Level in South Africa, 2016-2019" dalam Journal of Gender, Information, and Development in Africa (JGIDA), Special Issue (2019), h.113129.

Creswell, John W. Penelitian Kualitatif \& Desain Riset, edisi 3. Yogyakarta: Pustaka Pelajar, 2004.

Debus, Marc \& Martin Gross, "Coalition Formation at The Local Level: Institutional Constraints, Party Policy Conflict, and Office Seeking Political Parties" dalam Party Politics, Vol.22, No.6 (2015), h. 835-846.

Kluver, Heike \& Hanna Back. "Coalition Agreements, Issue Attention, and Cabinet Governance" dalam Comparative Political Study, Vol. 52, No. 13-14 (2019), h. 1995-2031.

Laver, Michael \& Kenneth Shepsle. "Coalition and Cabinet Government" dalam The American Political Science Review, Vol. 84, No. 3 (1990), h. 873-890.

Lijphart, Arend. Patterns of Democracy: Goverment Forms and Performance in ThirtySix Countries. New Heaven: Yale University Press, 1999. 
Mahpudin, Abdul Hamid \& Shanty Kartika Dewi. "Dinamika Koalisi Partai Politik dalam Pencalonan Kepala Daerah pada Pilkada Banten 2017" dalam Prosiding Seminar Nasional Prodi Ilmu Pemerintahan 2018, Banten, (2018).

Makhasin, Luthfi. "Orientasi Ideologi dan Pragmatisme Politik Model Pembentukan Koalisi dalam Pilkada Serentak di Jawa Tengah 2015" dalam Jurnal Ilmu Sosial dan Ilmu Politik, Vol.19, No.3 (2016), h. 234-250.

Martin, Lanny W. \& Georg Vanberg. Parliaments and Coalitions: The Role of Legislative Institutions in Multiparty Governance. Oxford: Oxford University Press, 2011.

Mietzner, Marcus. "Comparing Indonesia's Party Systems of The 1950s and The PostSuharto era: From centrifugal to centripetal inter-party competition" dalam Journal of Southeast Asian Studies, Vol.39 No 3 (2008), h. 431-453.

Moury, Catherine \& Arco Timmermans. "Inter-Party Conlict Management in Coalition Goverment: Analyzing The Role of Coalition Agreement in Belgium, Germany, Italy, and The Netherlands" dalam Politics and Governance, Vol.1, No. 2 (2013), h.117-131.

Moury, Catherine. "Coalition agreement and party mandate: How Coalition Agreements Constrain the Ministers" dalam Party Politics, Vol. 17, No.3 (2011), h. 385-404.

Muller, Wolfgang C. \& Thomas M. Meyer. "Meeting the Challenges of Representation and Accountability in Multi-party Governments" dalam West European Politics, Vol.33, No. 5 (2010), h.1065-1092.

Nazir, Moh. Metode Penelitian. Jakarta : Salemba Empat, 2003.

Riker, William Harrison. The Theory of Political Coalitions. New Haven: Yale University Press, 1962.

Sagarzazu, Inaki \& Heike Kluver. "Coalition Goverment and Party Competition: Political Communication Strategies of Coalition Parties" dalam Political Science Reserach and Metods, Vol. 5, No 2 (2017), h. 333-349.

Slater, Dan. "Indonesia's Accountability Trap: Party Cartel and Presidential Power After Democratic Transition" dalam Journal of Indonesia, Vol.78 (2004), h. 6192.

Spoon, Jae-Jae \& Heike Kluver, "Do Parties Respond ? How Electoral Context Influences Party Responsiveness" dalam Electoral Studies, Vol.35, No. C (2014), h. 48-60.

Vercesi, Michelangelo. "Coalition Politics and Inter-Party Conlict Management: A Theoritical Framework" dalam Politics and Policy, Vol.44, No. 2 (2016), h.168219. 
Warwick, Paul. Government Survival in Parliamentary Democracies. Cambridge: Cambridge University Press, 1994.

\section{Website}

Agus, Feri. "Menimbang Tiga Kandidat Pendamping Prabowo" dalam https://www.cnn indonesia.com/nasional/20180804205256-32-319581/menimbang-tiga-kandidatpendamping-prabowo diakses 5 Agustus 2018.

Azanella, Luthfia Ayu. "2 Tahun Anies Pimpin Jakarta Tanpa Wakil. Pencapaian Hingga Kontroversi" dalam https://www.google.com/amp/s/amp.kompas.com/tren/read/2019/10/16/160000965/2-tahun-anies-pimpin-jakarta-tanpa-wakil-penc apaian-hingga-kontroversi diakses 9 Januari 2021.

BBC news. "Prabowo Tujuk Sandiaga Uno Sebagai Cawapres Karena Percaya Diri?" dalam https://www.bbc.com/indonesia/indonesia-45133067 diakses 9 Agustus 2018 .

Dewi, Clara Maria Tjandra. "Berebut Kursi Bekas Sandiaga Uno, PKS Ungkit Lagi Janji Prabowo" dalam https://metro.tempo.co/read/1128614/berebut-kursibekas-sandiaga-uno-pks-ungkit-lagi-janji-prabowo/full\&view=ok diakses 21 September 2018.

Durohman, Ibad. "Tarian Poco-Poco Wagub Ibu Kota" dalam https://news.detik.com/x/detail/investigasi/20190904/Tarian-Poco-poco-WagubIbu-Kota/ diakses 4 September 2019.

Friana, Hendra. "Kader Gerindra dan PKS Saling Kunci Demi Mendampingi Anies Baswedan" dalam https://tirto.id/kader-gerindra-dan-pks-saling-kunci-demimendampingi-anies-baswedan-cV9f diakses 31 Agustus 2018.

Hantoro, Juli. "Ahmad Riza Patria Wagub, Pengamat: Kekuatan Lobi Gerindra" dalam https://metro.tempo.co/amp/1328457/ahmad-riza-patria-wagub--pengamat-keku atan-lobo-gerindra diakses 6 April 2020.

Hendro. "Sesuai Kesepakatan Pengganti Sandiaga Uno Adalah Kader PKS" dalam https://indonews.id/artikel/15121/Sesuai-Kesepakatan-Pengganti-Sandiaga-UnoAdalah-Kader-PKS/ diakses 10 Agustus 2018.

Jurnaliston, Reza. "Mencari Pengganti Sandiaga Uno, Apakah Gerindra Mau PKS Setengah Hati ?" dalam https://nasional.kompas.com/read/2018/09/20/ 09300681/mencari-pengganti-sandiaga-apakah-gerindra-mau-pks-setengah-hati? page $=$ all diakses 20 September 2018.

Nugroho, Iqbal S. "Gerindra dan PKS Resmi Bercerai" dalam https://www.merdeka.com/ politik/gerindra-dan-pks-resmi-cerai.html?page=all diakses 21 Februari 2020. 
Sari, Nursita. "Ribet Banget Drama Gerindra dan PKS Pilih Wagub" dalam https:// megapolitan.kompas.com/read/2020/01/21/09571441/ribet-banget-dramagerindra-dan-pks-pilih-wagub-?page=all diakses 21 Januari 2020.

Setiawan, Riyan. "Menang Telak, Riza Patria Terpilih Sebagai Wagub Jakarta” dalam https://tirto.id/menang-telak-riza-patria-terpilih-sebagai-wagub--jakarta-eLjv diakses 6 April 2020. 